\title{
Infância, criança e a experiência humana do tempo ${ }^{1}$
}

\author{
Laurici Vagner Gomes ${ }^{2}$
}

laurici_gomes@uol.com.br

\begin{abstract}
Resumo
O presente trabalho tem como foco o problema da identidade entre criança e infância, partindo da caracterização de importantes elementos históricos e filosóficos envolvidos na construção dessa identidade, passando por Heráclito, Platão, Nietzsche, Foucault e Hannah Arendt. Nesse percurso, pretendemos gerar uma reflexão sobre as bases nas quais essa identidade é construída, partindo de aspectos que envolvem a caracterização da experiência humana do tempo.
\end{abstract}

Palavras-chave: Infância; criança; tempo; educação; natalidade.

A nova resolução ${ }^{3}$ para o curso de pedagogia define que a educação infantil e o ensino fundamental são os espaços, por excelência, de atuação do profissional pedagogo. O presente trabalho encontra seu solo de origem nesse contexto; na observância das discussões geradas pela nova resolução. Nossa proposta é provocar o que para muitos pode ser uma obviedade: a identidade construída entre criança e infância para a partir disso, abrir discussões sobre o que entendemos por educação infantil. Problematizar a identidade entre infância e criança pode soar

1 Texto originalmente produzido para apresentação no "Ciclo de debates sobre o novo currículo do curso de pedagogia", promovido pela Faculdade de Educação da Universidade do Estado de Minas Gerais em fevereiro de 2009.

2Doutorando e Mestre em Filosofia pela Universidade Federal de Minas Gerais (UFMG), graduado em Ciências Sociais pela Universidade Estadual Paulista (UNESP), professor do Departamento de Fundamentos Sócio-Histórico Filosóficos da Educação e coordenador do Núcleo de Estudos e Pesquisas em Filosofia e História da Educação da Universidade do Estado de Minas Gerais (UEMG). Professor de Sociologia na Educação Básica da Rede Estadual de Minas Gerais.

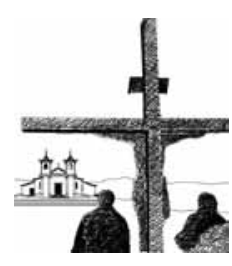

61 
estranho aos ouvidos, pois a tradição ocidental construiu uma identificação quase que absoluta entre um termo e outro, cuja base se encontra numa compreensão linear do tempo pela qual se configura a crença num desenvolvimento contínuo do humano, em que a infância aparece como uma primeira etapa da vida, demarcada por faixas etárias e consequentemente suprimida pela vida adulta. Nossa discussão trará alguns elementos para provocar essa visão cristalizada.

\section{A identidade entre criança e infância}

\subsection{Educação, cultura e natalidade}

A filósofa alemã Hannah Arendt, no único texto em que se debruça de maneira mais direta sobre o tema da educação, intitulado "A crise na educação", escrito em 1958 e publicado na coletânea de textos chamada "Entre o passado e o futuro", afirma que é em tempos de crise que se revela a verdadeira essência da educação. Arendt compreende a crise como oportunidade que "dilacera fachadas e oblitera preconceitos - de explorar e investigar a essência da questão em tudo aquilo que foi posto a nu, e a essência da educação é a natalidade, o fato de que seres nascem para o mundo" (ARENDT, 1997, p. 223). Segundo a filósofa, a crise nos revela que a educação é uma "obrigação imposta aos homens pelo fenômeno da natalidade", a obrigação de introduzir novos seres num mundo velho. De acordo com Arendt, é muito simplista acreditar que a crise na educação em nossa sociedade é localizada ou é meramente uma crise dos métodos educacionais.

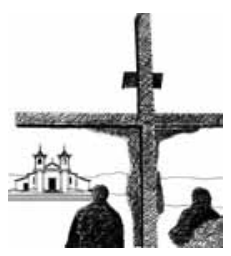
Sendo mais profunda a natureza do problema, faz-se necessário pensar nas relações entre cultura e educação.

Por que podemos vislumbrar a existência de processos educacionais em todas as culturas humanas? Porque em todos os momentos históricos, em todos os contextos no quais se desenvolve a vida social humana, novos seres nascem para o mundo, mundo que não começou com eles e que deverá continuar 
para além da condição finita de cada indivíduo.

Como afirma Arendt, a criança enquanto um recém-chegado em estado de vir-a-ser possui para o educador um duplo aspecto: é um novo ser humano e é um ser humano em processo de formação. A criança compartilha esse estado de vir-a-ser com todas as coisas vivas. Nesse sentido, é um ser humano em processo de formação assim como qualquer filhote animal o é. Mas é somente em relação a um mundo pré-existente, um mundo velho, que a criança é nova, ou seja, a criança não é nova porque ainda não desenvolveu as potencialidades da espécie, porque ainda não se transformou em adulto, pois se assim fosse

a educação seria apenas uma função da vida e não teria que consistir em nada além da preocupação para com a preservação da vida e do treinamento e na prática do viver que todos os animais assumem em relação aos seus filhos (ARENDT, 1997, p. 235).

"Educar para preservar a vida": isso compartilhamos com todos os outros animais. "Educar para a continuidade do mundo": isso é tipicamente humano.

Nesse sentido, a educação, entendida como obrigação imposta aos homens pelo fenômeno da natalidade, desdobra-se em duas responsabilidades: "responsabilidade para com a preservação da vida e responsabilidade para com a continuidade do mundo". Segundo Arendt, essas duas responsabilidades de modo algum coincidem, podendo, inclusive, entrar em conflito mútuo. Isso porque para um bom desenvolvimento da vida humana finita, a criança deve ser protegida do mundo, assim como o próprio mundo simbólico deve também ser protegido desses recém-chegados para que não seja destruído a cada geração pelo assédio do novo.

Nas sociedades tribais, podemos observar quea "endoculturação", a introdução dos novos seres na cultura, dava-se pela reprodução dos arquétipos do passado realizada através dos processos educacionais. $\mathrm{O}$ homem é introduzido na cultura na medida em que aprende e repete os modelos de conduta advindos do passado. Esses modelos foram

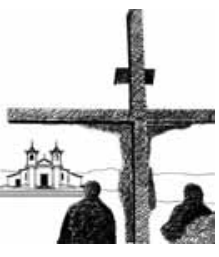

63 
criados pelos deuses e transmitidos aos antepassados: o passado é assim oracular. Analisando o sentido assumido pela educação numa sociedade caracterizada como "tradicionalista, sagrada e fechada", o sociólogo Florestan Fernandes, em sua pesquisa sobre a educação entre os tupinambás, afirma:

"Inovação" e "tradição" interpenetram-se de tal modo, que uma conduz à outra, podendo se afirmar: 1) que toda inovação, por mais radical que seja, lança raízes no passado e se alimenta de potencialidades dinâmicas contidas na tradição; 2) que a inovação já nasce, culturalmente, como tradição, como "experiência sagrada" de um saber que transcende ao individuo e ao imediatismo do momento (FERNANDES, 1975, p. 36).

Se, nas sociedades tradicionais, os mecanismos que garantem a continuidade do mundo simbólico através da repetição dos modelos do passado conseguem proteger esse mundo do abalo produzido pela irrupção do novo a cada geração, promovido pelo fenômeno da natalidade, com o advento da atividade filosófica na sociedade grega e a problematização desses mecanismos, outra relação entre natalidade e educação começa a ser gerada.

Em seu livro "Infância. Entre educação e filosofia", Walter Kohan afirma que apesar da inexistência do termo infância entre os gregos, os diálogos platônicos contribuíram fundamentalmente para a formação desse conceito que foi se cristalizando na filosofia da educação ocidental. A tese defendida por Kohan é que a infância era parte indissociável de algo que constituiu um problema fundamental para a filosofia platônica que seria "entender, enfrentar e reverter a degradação cultural, política e social da Atenas do seu tempo" (KOHAN, 2003, p. 27). É no interior de um projeto político de mudança social para o qual se volta sua filosofia que o fenômeno da infância interessa ao filósofo.

O sentido originário da palavra infância vem impregnado por aquilo que os antropólogos chamam de "signo da falta". O que se destaca a partir do termo infância são conjuntos de ausências que 
devem ser preenchidas a partir do vir-a-ser adulto. Platão não usa o termo infância, mas o conjunto de ausências vinculado por esse termo está presente no tratamento dado pelo filósofo às crianças, ausências que são preenchidas pelas utopias políticas dos adultos. Podemos observar, a partir do pensamento platônico, que o trabalho de conservação do passado realizado pelos processos educacionais começa a ser invadido pelas projeções de futuro dos adultos.

Como afirma Kohan, não só na república platônica como em toda educação formadora em sentido clássico, se apresenta a

tentação de apropriar-se da novidade dos novos, à tentação de fazer da educação uma tarefa eminentemente política e da política o sentido final de uma educação, a partir de uma lógica da política determinada com independência da vontade dos novos (KOHAN, 2003, p. 58-59).

O sentido e a importância dada à educação das crianças nos diálogos platônicos são marcados pelo vir-a-ser adulto, mas é fundamental observarmos que esse vir-a-ser adulto não significa a realização do homem, seu acabamento. $\mathrm{O}$ drama do adulto diante da vida humana finita e seu inacabamento é o solo de onde se origina a tentação de apropriar-se da novidade dos novos, marcando o corpo e o espírito das crianças com suas visões e projeções do futuro, com suas utopias políticas. Somamos a esse aspecto outro que conduz os adultos a roubarem a novidade da criança, a crença naquilo que Nietzsche chama, no "Crepúsculo dos ídolos", de "melhoramento da humanidade". Nesse sentido, as crianças devem ser educadas não só porque serão os futuros governantes da polis, mas pela possibilidade de realizarem as utopias, os sonhos que os adultos não realizaram.

Se nas sociedades tradicionais, a novidade dos recém-chegados era roubada pelo passado oracular, no modelo de sociedade utopicamente pensada por Platão, a novidade dos recém-chegados é roubada pela crença no devir progressivo da humanidade que alimenta as projeções de futuro dos adultos. O advento das

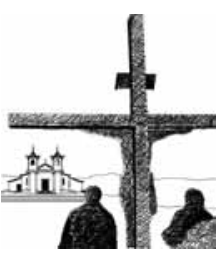


concepções teleológicas do tempo produz radicais transformações no sentido assumido pelos processos educacionais e colocam o homem diante de uma nova relação com o fenômeno da natalidade.

\subsection{A identidade entre criança e infância e a experiência teleológica do tempo}

Testemos uma primeira afirmação: identificar o fenômeno da infância na criança é enquadrá-la numa concepção linear do tempo marcada não só pelo vir-a-ser adulto, mas também pelo vir-a-ser novo alimentado pela crença do adulto num devir progressivo do homem. Como nos apresenta Hannah Arendt, diante das crianças, dos recém-chegados, o adulto é sempre um representante do mundo velho, um representante que deve assumir não só a responsabilidade pela preservação da vida, mas fundamentalmente a responsabilidade pela continuidade do mundo. Diante disso, partindo do fato de que é sempre um adulto que educa a criança, Arendt revela o contrassenso presente na ideia de se educar para o novo, pois este "novo" é sempre o novo do adulto.

Arendt, a partir disso, problematiza a vinculação entre educação e política: a política é a atividade que se volta para o novo, para a mudança social. A natureza da educação, segundo a filósofa, é outra, a educação é sempre conservadora. Nesse sentido, é um contrassenso querer educar para o novo, sendo que, ao se vincular a esse propósito, a educação invade o campo da política, impossibilitando que o novo surja. Segundo Arendt, educar para o novo é retirar dos recém-chegados, dos verdadeiramente novos, a possibilidade de serem novos.

As ideias modernas de progresso e desenvolvimento,

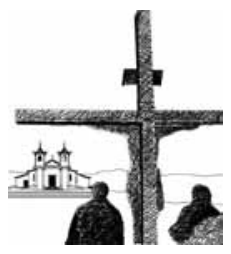
resultantes de outra relação do homem com a história, trouxeram novos elementos para se pensar na educação enquanto "endoculturação". Nesse mundo moderno, em que a ciência passa a trabalhar para o desenvolvimento tecnológico e ele se torna a mola propulsora da crença no progresso, a ligação do homem com a tradição se enfraquece, pois o passado é visto como algo 66 que deve ser superado pelo presente, que, por sua vez, é superado 
pelo futuro. Nesse contexto, como pensar na educação enquanto endoculturação? Como introduzir os recém-chegados numa cultura em que, usando a célebre expressão de Marx, "tudo que é sólido desmancha no ar"? A educação que se volta para o futuro se concentra na tarefa de superar o passado. Para essa finalidade, acreditamos que os processos educacionais devem acompanhar o ritmo do desenvolvimento tecnológico e das transformações científicas, pois eles sustentam a crença no progresso.

Segundo Arendt, o sinal mais agudo da crise atual legada pela modernidade é a perda do senso comum, da realidade compartilhada, sendo que essa perda resulta justamente do enfraquecimento da autoridade da tradição a que nos conduziu o "pathos do novo" que caracteriza a cultura moderna. Podemos dizer que a problematização do senso comum e a crença no devir progressivo do homem, presente na filosofia platônica, estão na origem desse movimento que acabou por gerar uma profunda crise na educação. Para a autora de "A condição humana",

o conservadorismo, no sentido da conservação, faz parte da essência da atividade educacional, cuja tarefa é sempre abrigar e proteger alguma coisa, a criança contra o mundo, o mundo contra criança, o novo contra o velho, o velho contra o novo (ARENDT, 1997, p. 242).

Na perspectiva de Arendt, que a educação assuma seu caráter conservador é fundamental para que o mundo não se torne mortal como os mortais, para que o mundo continue e se renove a cada nova geração. Chegamos ao centro das argumentações da filósofa sobre educação quando compreendemos o sentido dessa conservação e do contrassenso arraigado na ideia de educar para o novo. Diz Arendt:

Basicamente, estamos sempre educando para um mundo que, ou já está fora dos eixos, ou para aí caminha, pois é esta a situação humana básica, em que o mundo é criado por mãos mortais e serve de lar aos mortais durante tempo limitado. $\mathrm{O}$ mundo, visto

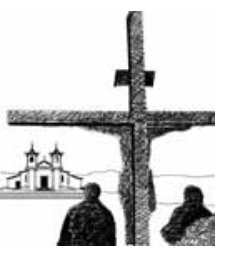

67 
que feito por mortais, se desgasta, e, dado que seus habitantes mudam continuamente, corre o risco de tornar-se mortal como eles. Para preservar o mundo contra a mortalidade de seus criadores e habitantes, ele deve ser, continuamente, posto em ordem. O problema é simplesmente educar de tal modo que um por-em-ordem continue sendo efetivamente possível, ainda que não possa, é claro, ser assegurado. Nossa esperança está pendente sempre do novo que cada geração aporta; precisamente por basearmos nossa esperança apenas nisso, porém, é que tudo destruimos se tentarmos controlar os novos de tal modo que nós, os velhos, possamos ditar sua aparência futura. Exatamente em benefício do que é novo e revolucionário em cada criança é que a educação precisa ser conservadora; ela deve preservar esta novidade e introduzila como algo novo em um mundo velho, que, por mais revolucionário que possa ser em suas ações, é sempre, do ponto de vista da geração seguinte, obsoleto e rente à destruição (ARENDT, 1997, p. 245).

O mundo é criado pelos humanos mortais, finitos, mas não deve ser mortal como eles. É necessário então conservá-lo, protegêlo da finitude de seus criadores. Educaremos então as crianças para que elas continuem o mundo simbólico do adulto? É essa a posição de Arendt? Não, para a filósofa, ao contrário do que podemos ver nas sociedades tradicionais que fundamentam sua ordem simbólica num passado oracular, a continuidade do mundo depende de sua renovação. Nesse sentido, a educação não pode retirar das mãos daqueles que são verdadeiramente novos, as

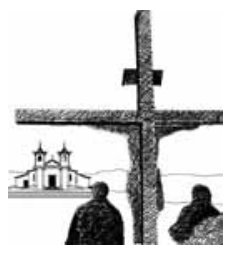
crianças, os recém-chegados, a possibilidade de gerar uma nova ordem, pois é dessa forma que o mundo se renova. Mas isso só se torna possível, segundo a filósofa, se a educação, assumindo seu caráter conservador, preservar o mundo da finitude de seus criadores, pois é em relação ao mundo velho que a criança é nova. O papel do educador se coloca então numa encruzilhada entre o 
passado e o futuro: como representante do mundo velho deve apresentá-lo para a criança e, ao mesmo tempo, deve preservar sua novidade. O problema está colocado: "como introduzir a criança, o verdadeiramente novo, o recém-chegado, num mundo velho sem retirar de suas mãos a novidade?"

Diante dessa instigante e complexa questão colocada por Arendt, defenderemos a tese de que enfrentá-la requer não só romper com as imagens da criança marcadas pelo vir-a-ser adulto e pelo vir-a-ser novo articuladas a partir da crença num devir progressivo da humanidade. Essas imagens estão na própria base de estruturação do conceito de infância, mas nos provoca fundamentalmente a mudar esse conceito, construído tradicionalmente a partir da crença num desenvolvimento contínuo do humano alicerçado sobre as bases de uma concepção linear do tempo e de sua identificação com a criança. Em outros termos, "é fundamental pensar a criança como portadora de outra experiência do tempo".

\section{A desconstrução da identidade entre criança e infância}

\subsection{A dissolução das imagens da criança construídas pelo adulto}

Dissolver as imagens construídas da criança como um adulto em miniatura e configurar, como diz Arendt, um "mundo da criança" independente, autônomo, próprio: esse movimento demarca o conceito de infância que vem à tona com a modernidade e que, em termos gerais, explica o sentido das concepções, métodos e práxis que singularizam o que chamamos de "educação infantil" frente a outras formas de educação. Mas será que esse novo saber sobre a infância possibilita o rompimento com as imagens da criança construída pelo adulto e por suas projeções de futuro? Ao contrário do que acontecia até então, no século XVII, a infância passou a ser mais diretamente qualificada como um período que

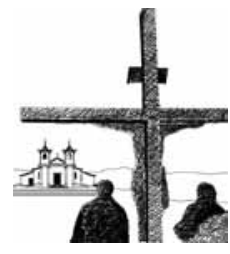

69 
compreendesse determinadas faixas etárias, caracterizado como a primeira etapa do desenvolvimento humano. Sendo assim, aqueles que se encontrassem nesse período passaram a ser identificados por possuírem especificidades e necessidades próprias. Foi também o momento em que o cuidado com a vida e com o caráter das crianças deixou de ser algo de exclusiva responsabilidade das famílias e passou a ganhar o interesse do Estado no contexto de um movimento mais amplo, em que as demandas da vida humana finita por condições de sobrevivência, trabalho, bemestar, segurança, entre outras, passaram a ser forças motrizes do mundo público. O Estado, por sua vez, passou progressivamente a invadir a esfera privada das relações íntimas.

Na modernidade, como diz Kohan, com a "invenção ou a intensificação dos sentimentos em torno da infância, a educação passa a ser, como de certa forma queria Platão, uma questão de Estado" (KOHAN, 2003, p. 91). Mas é bom dizermos que esse Estado não é mais aquele conforme projetava Platão, um Estado que, para garantir uma polis justa, necessitava de homens formados para a virtude moral e para a verdade, gerados pela educação da alma, pela ascese, cuja finalidade é o conhecimento metafísico do bem em si como única forma de compreensão do bem-comum. Se, alimentada pela utopia platônica, a educação das crianças é movida pela crença no devir progressivo do homem e angariada nas imagens de futuro dos adultos, conforme já discutido, na modernidade essa crença se mantém, mas o seu alvo não é mais a virtude moral e a verdade, e sim a normalidade. Em síntese, a crença num devir progressivo da humanidade se mantém, mas ela passará a fundamentar-se nas imagens de futuro idealizadas por um adulto normalizado. A utopia é a normalidade: da moral da virtude passamos a uma moral da normalidade.

Segundo Nietzsche, o Estado Moderno é o bastião da domesticação civilizatória operada através da utilização do cristianismo enquanto técnica de dominação, cujo produto máximo é o homem gregário, comum, rebanho, portador de ideais de 
bem-estar, paz e igualdade. Nesse caminho aberto por Nietzsche, Foucault analisa as formas de exercício do poder nas instituições modernas e a maneira como se opera a dominação do Estado através da adaptação do poder pastoral cristão às suas necessidades. $\mathrm{Na}$ relação entre o Estado Moderno e suas instituições, assistimos a articulação entre o poder disciplinar e o pastoral.

Foucault dá o nome de disciplina à forma característica de exercício do poder que vem à tona nas sociedades dos séculos XVII e XVIII, sendo que a função principal do poder disciplinar é normalizadora: gerar um indivíduo apto a governar sua conduta dentro da normatividade que distingue o certo e o errado, o são e o insano, o proibido e o correto. Dessa forma, fabricar "homens úteis". Na medida em que o poder disciplinar individualiza, produz indivíduos aptos a serem submetidos à forma de dominação característica do poder pastoral, forma de organização do poder que remonta aos hebreus e que foi ligeiramente modificada pelos cristãos.

O poder pastoral é o poder que se origina da relação entre o pastor e seu rebanho, em que: 1) se estabelece um vínculo moral entre o pastor e cada membro de seu rebanho, sendo que o primeiro deve assumir a responsabilidade por todos os atos do segundo; 2) a relação entre pastor e rebanho é caracterizada pela dependência absoluta, sendo a obediência entendida como virtude; 3) o pastor deve conhecer com precisão o que acontece no interior da alma de cada membro de seu rebanho e 4) o pastor deve por em prática técnicas de exame, confissão e direção da consciência para induzir os membros do rebanho a renunciarem constantemente este mundo e a si mesmo.

A modernidade assiste ao desenvolvimento da escola, uma instituição que será, em grande parte, a responsável pela intensificação dos sentimentos relativos à infância. Nesse sentido, é fundamental, como argumenta Kohan, observar que essa intensificação é gerada por uma instituição moldada por dispositivos disciplinares e também invadida pelo poder pastoral.

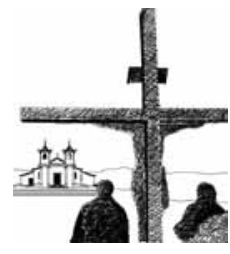


É essa instituição, responsável pela construção de um saber/ poder sobre a infância, que progressivamente será a responsável pela introdução das crianças, dos recém-chegados, no mundo. Podemos dizer que a escola mais do que possibilitar e aplicar um saber sobre a infância, através dos seus dispositivos disciplinares, produzirá a infância.

Através da escola, a criança, o recém-chegado, o ser novo é introduzido no mundo a partir de uma série de representações específicas reconhecidas socialmente como pertencentes ao "mundo da criança", produzindo sobre o corpo e o espírito do ser novo o ser infantil. O ser criança é produzido pelo saber sobre a infância e é introduzido no mundo simbólico na medida em que se percebe e se reconhece como infantil aos olhos de um professor adulto representante do mundo púbico, do poder pastoral do Estado. O professor-pastor produz a infância na criança, vigiando-a e conduzindo-a e como guardião de seu futuro, responde pelo seu desenvolvimento. Nesse sentido, produzir a infância na criança é colocá-la no início da linha de desenvolvimento contínuo do humano rumo à normalização, movimento compreendido como imprescindível para o progresso social alimentado pela crença numa concepção teleológica do tempo, angariada principalmente nos avanços da ciência e no desenvolvimento tecnológico que marcam as projeções de futuro do adulto normalizado. Nesse contexto, se torna extremamente significativa a afirmação de Foucault que na escola as crianças são prisioneiras de uma infantilização que não é delas ${ }^{4}$.

Segundo Arendt, a instituição escolar deve sua origem a um movimento da sociedade moderna de rejeição da distinção entre a esfera do publico e do privado, que por sua vez configura uma nova relação entre as forças que se voltam para o exercício da responsabilidade para com a vida humana finita e as que se voltam para o exercício da responsabilidade pela continuidade do mundo.

4 "Não são apenas os prisioneiros que são tratados como crianças, mas as crianças como prisioneiras. As crianças sofrem uma infantilização que não é delas. Neste sentido, é verdade que as escolas se parecem um pouco com as prisões, as fabricas se parecem muito com as prisões" (FOUCAULT; DELEUZE, 1999, p. 73). 
Segundo Arendt, a esfera pública é o âmbito em que se exerce a responsabilidade pela continuidade do mundo em detrimento da vida finita dos mortais, sendo que é na esfera privada, na família, que se constitui como "um escudo contra o mundo e, sobretudo, contra o aspecto público do mundo" (ARENDT, 1997, p. 236), que a responsabilidade com a vida individual finita se exerce.

A rejeição dessa distinção na modernidade resulta de um processo no qual a responsabilidade para com a vida individual finita progressivamente deixa a esfera privada e invade a pública. O Estado passa a ser o responsável pela conservação da vida e pelo devir individual de seus membros, por suas demandas de sobrevivência, condições de vida, progresso futuro, prosperidade e trabalho. Como efeito disso, a esfera pública invade a privada e passa a desenvolver mecanismos de controle e vigilância sobre a vida dos indivíduos na tentativa de "conciliar" o devir dos indivíduos e o do Estado.

Para Arendt, a educação moderna procurou constituir um "mundo da criança" independente do mundo adulto, procurando libertá-la dos padrões desse mundo, mas acabou por destruir "as condições necessárias ao desenvolvimento e crescimento vital" (ARENDT, 1997, p. 236) à medida que expôs as crianças à existência pública, o que é típico do mundo adulto, o que seria um contra-senso da educação moderna. A filosofia diz que quanto

mais completamente a sociedade moderna rejeita a distinção entre aquilo que é particular e aquilo que é público, entre o que somente pode vicejar encobertamente e aquilo que precisa ser exibido a todos à plena luz do mundo público, ou seja, quanto mais ela introduz entre o privado e o público uma esfera social na qual o privadoé transformado em público e vice-versa, mais difíceis tornam as coisas para suas crianças, que pedem, por natureza, a segurança do ocultamento para que não haja distúrbios em seu amadurecimento (ARENDT, 1997, p. 238).

A perda da autoridade da tradição devido ao "pathos do

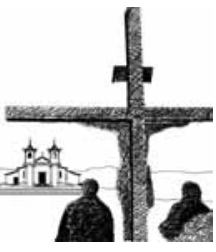

73 
novo" alterou a existência pública, que deixou de ser o âmbito da realidade compartilhada, do senso comum, gerado pela consciência do pertencimento a um passado comum, e passou a ser o âmbito em que se opera a normalização como forma de conciliar o devir individual e o devir do Estado que, através do exercício do poder pastoral, constrói a imagem de um futuro comum, angariado numa concepção teleológica do tempo, sustentada pela crença no desenvolvimento científico e tecnológico. Expostas à esfera pública, as crianças se tornam vítimas dos mecanismos de normalização.

Ao assumir a responsabilidade pelas demandas da vida privada e devido aos efeitos gerados por esse comprometimento, a esfera publica deixa de ser o âmbito de exercício da responsabilidade pela continuidade do mundo na medida em que passa a concentrar seus esforços nos mecanismos de normalização. $\mathrm{O}$ progresso futuro depende desses mecanismos. Na medida em que a educação passa a ser movida pelo "pathos do novo", que move a cultura moderna, alicerçada nas visões de um futuro redentor para humanidade, passando a ser um dos pólos de exercício dos mecanismos de normalização, mais se distancia de sua essência: introduzir seres novos num mundo velho. Na medida em que a educação mais se afasta de sua essência, mais se torna um mecanismo que rouba a novidade dos recém-chegados, colocando, dessa forma, a continuidade do mundo em xeque. A normalização impede que o mundo se renove e, assim, obstrui sua continuidade.

Arendt caracteriza como "crise da autoridade na educação", o sintoma mais agudo da progressiva perda da responsabilidade pela continuidade do mundo, sintoma que "guarda a mais estreita conexão com a crise da tradição, ou seja, com a crise de nossa atitude face ao âmbito do passado" (ARENDT, 1997, p. 243). Para que o mundo continue, é necessário que o educador torne-se uma ponte entre o velho e o novo. Para isso, deve nutrir um "respeito extraordinário pelo passado" (ARENDT, 1997, p. 244). Mas na medida em que o educador se torna um professor-pastor que disciplina as crianças para entrarem na "marcha do progresso", o 
respeito pelo passado vai sendo dissolvido. Dessa forma, deixando de ser uma ponte entre o velho e o verdadeiramente novo, ele compromete a continuidade do mundo na medida em que rouba a novidade do novo ao submetê-la às projeções de futuro dos adultos, impedindo que o mundo se renove.

Arendt nos leva a pensar até que ponto a construção do "mundo da criança" pela educação moderna serviu para desatrelar a criança da tirania do adulto e a libertou das imagens do vir-a-ser adulto e do vir-a-ser-novo, construídas pelo adulto. Mesmo procurando romper com as imagens da criança como um adulto em miniatura, o saber sobre a infância produzido pela modernidade, responsável pela construção desse mundo simbólico da criança distinto do mundo adulto, continua, na medida em que a infância é caracterizada como uma etapa da vida, entendida como um marco inicial no desenvolvimento contínuo e linear humano, a ser um terreno configurado e ocupado pelas projeções de futuro dos adultos.

Como introduzir a criança, o recém-chegado no mundo sem roubar-lhe a novidade? Essa questão arendtiana é especialmente desafiadora para a pedagogia que, na modernidade, com a intensificação dos sentimentos relacionados à infância, passa a ser legitimada como ciência na medida em que aplica os saberes produzidos sobre a infância na produção de um tipo específico de criança. Através da caracterização de um "mundo da criança", a pedagogia moderna se ocupará em produzir uma forma particular de subjetividade infantil. Como nos diz Kohan, antes da modernidade, já existiam ideias, práticas e saberes pedagógicos sobre as crianças. Porém, o que não existia previamente era a pedagogia como ciência, como moral e como política do conhecimento, como desejo de conhecer e estudar o corpo das crianças, seus desejos, seus brinquedos, seus pensamentos e capacidades intelectuais.

Nesse sentido, Arendt nos obriga a repensar o sentido da educação infantil construído historicamente pela pedagogia e nos impõe como tarefa construir em outras bases o sentido e a práxis que a envolve. Em nossa perspectiva, esse movimento nos

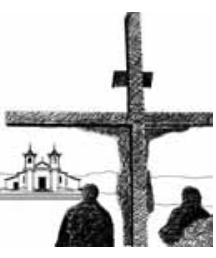


provoca a mudar a ideia de infância construída tradicionalmente a partir da crença num desenvolvimento contínuo do humano, construído sobre as bases de uma concepção linear do tempo, e sua identificação com a figura da criança caracterizada por um conjunto de ausências que as transformaram em solo para as projeções do adulto. Para essa finalidade, pensaremos a criança como portadora de outra experiência do tempo. Faremos isso com o auxílio de dois filósofos: Heráclito e Nietzsche.

\subsection{A criança como portadora de outra experiência do tempo}

A filosofia de Heráclito guarda as marcas do processo de "dessacralização" da vida pública grega marcada pelo comumente chamado processo de transição do mito ao logos, que também caracteriza a filosofia socrático-platônica. Se nos ativermos à leitura nietzscheana de Heráclito, vislumbraremos no pensador de Éfeso, o advento de outra cultura que Nietzsche caracteriza como cultura trágica, que fora esmagada pelo homem teórico com sua lógica da identidade e sua tentativa de corrigir os abismos da existência, cujo primeiro movimento se encontra, justamente, na filosofia socrático-platônica. É dessa tradição vitoriosa, do homem teórico, que advém a imagem de Heráclito como um pensador obscuro. Donaldo Schüler, no livro "Heráclito e seu (dis)curso", diz:

Heráclito brinca com as palavras como se fossem dados. A poesia requer o sacrifício da seriedade, busca os caminhos que levam ao mundo da criança, ainda não afetado pelas leis que delimitam os possíveis do adulto (SCHÜLER, 2007, p. 71).

Operando com a linguagem através do logos do jogo, Heráclito afronta a sua época em que, nas cidades que se democratizam, a palavra se torna uma arma. Esse também é o contexto de Platão, mas o logos de Heráclito é outro. O logos de Heráclito requer a ampliação do mundo, um mundo em que a contradição não deve 
ser expulsa pela lógica da identidade, e sim experimentada e manifestada na linguagem como um caminho que nos conduz a unidade de todas as coisas. Onde buscar essa linguagem? Na poesia que requer o sacrifício da seriedade e que nos conduz ao mundo da criança, um mundo ainda não afetado pelos possíveis dos adultos, adultos para os quais a contradição deve ser expulsa dos discursos, para os quais a contradição não é possível. A criança nos convida a entrar no discurso-rio de Heráclito. O filósofo de Éfeso diz no fragmento 12: Para aqueles que se banham nos mesmos rios, fluem águas distintas e distintas (KOHAN, 2003, p. 128)

Heráclito joga com oposições. Oposição entre a identidade dos rios e a distinção das águas que fluem neles. Os mesmos rios reúnem em si águas distintas e, dessa forma, manifestam a unidade que se estabelece na distinção, na diferença, na alteridade. Para isso é necessário entrar no rio. Somente entrando no rio, vislumbramos o fluxo de águas distintas que compõe a unidade-rio, unidade que se torna mais perceptível na medida em que saímos do rio, pois quanto mais distantes, menos perceptível o fluir das águas. Os banhistas compreendem, diferentemente daqueles que contemplam o rio de fora, que a unidade-rio é construída sobre o fluxo de suas águas distintas. Os banhistas jogam e isso significa, segundo Deleuze, que procuram a correlação do um com o múltiplo ${ }^{6}$, do ser-rio com o devir de suas águas. Jogar é entrar e sair do rio várias vezes. É através desse movimento que os banhistas escutam o logos que se revela na dinâmica do Aión manifestada no jogo sem moral da criança que brinca de construir e destruir castelos, logos que é a possibilidade sempre renovada de reunir o múltiplo no um.

É fundamental entrar e sair do rio: a criança de Heráclito nos convida a esse movimento. Se não entrarmos no rio, não perceberemos que a unidade se mantém no fluxo, na luta dos contrários, no jogo das oposições que caracteriza o mundo vivo.

5 DK 22 B 12 apud KOHAN, 2003, p. 128.

6 "A correlação do múltiplo e do um, do devir e do ser forma um jogo. Afirmar o devir, afirmar o ser do devir são dois tempos de um jogo que se compõem com um terceiro termo, o jogador, o artista ou a criança" (DELEUZE, 1976, p. 20).

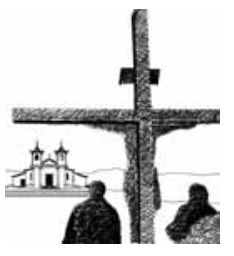


Se não entramos no rio, as palavras se congelarão na fixidez ilusória dos conceitos, se cristalizarão na gramática e na lógica da identidade. Desse modo, vislumbraremos uma unidade ilusória, estanque, não viva. Se não entrarmos no rio, não experimentaremos o tempo da vida: tempo governado pela criança. Afirma Heráclito no célebre fragmento 52 . O tempo da vida é uma criança que joga um jogo de oposições. De uma criança, seu reino (HERÁCLITO DK 52 apud KOHAN, 2003, p. 147).

Aparecem em Heráclito dois usos do termo "criança". Um primeiro mais coloquial, que caracteriza a criança como paidós, um não adulto. Um segundo como aquilo que não tem oposições, que joga com as oposições. Nesse segundo termo, a criança passa a caracterizar o tempo da vida (Aión). Aión não é o tempo marcado pela continuidade, demarcado pelas fronteiras do passado, presente e futuro, também não é o tempo mensurado (Chrónos), é um tempo compreendido como destino, do nascimento e da morte, do vir-a-ser e do perecer, da criação e da destruição. Mas por que o tempo como Aión, o tempo da vida, é o reino da criança?

Nietzsche, em "A filosofia na época trágica dos gregos", escrito de 1873, numa seção em que discute a filosofia de Heráclito, recupera essa associação do filósofo de Éfeso:

Neste mundo, só o jogo do artista e da criança tem um vir à existência e um perecer, um construir e um destruir sem qualquer imputação moral em inocência eternamente igual. E, assim como brincam o artista e a criança, assim brinca também o fogo eternamente activo, constrói e destrói em inocência eternamente igual. $\mathrm{E}$, assim como

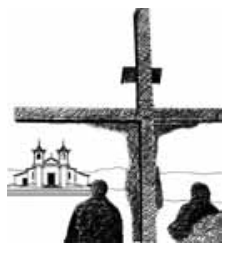

78 brincam o artista e a criança, assim brinca o fogo eternamente activo, constrói e destrói em inocência - e esse jogo joga o Aión consigo mesmo. Transformando-se em água e em terra, junta, como uma criança, montinhos de areia à beira-mar, constrói e derruba: de vez em quando recomeça o jogo. Um instante de saciedade: depois, a necessidade se apodera outra vez dele, tal como a necessidade força

Ano 13 - n. 15 - julho 2010 - p. 61-92 
o artista a criar. Não é a perversidade, mas o impulso do jogo sempre despertando de novo que chama outros mundos à vida. Às vezes, a criança lança fora o brinquedo: mas depressa recomeça a brincar com uma disposição inocente. Mas, logo que constrói, liga e junta as formas segundo uma lei e em conformidade com uma ordem intrínseca (NIETZSCHE, 1995, seção VII).

A língua grega reúne num mesmo termo, $p^{2} a z^{7}$, o jogar e o brincar. O tempo da vida (Aión) é regido pela dinâmica do jogarbrincar. No tempo da vida, as coisas são geradas e destruídas, assim como uma criança que brinca de construir e destruir castelos. Como nos diz Nietzsche na passagem citada, a identidade entre o Aión e a criança, assim como também com o artista, se dá pelo fato de que esses entram na dinâmica do construir e destruir através do jogar/brincar sem nenhuma imputação moral em que a destruição potencializa a criação. Para Nietzsche, o movimento do Aión desconhece moralidade, mais do que isso, a moral surge do ressentimento diante da dinâmica do Aión. Dar uma imputação moral ao jogar/brincar manifesta esse ressentimento. O pensamento moral tem uma dinâmica distinta do jogo e acaba por destruir a dinâmica que o envolve.

Segundo Nietzsche, o ressentimento do homem diante da dinâmica do Aión marca a cultura ocidental, pois está na base daquilo que o filósofo caracteriza como pensamento metafísicomoral, que se manifesta no platonismo e depois no cristianismo, religião em que esse pensamento se torna mais capcioso, um "platonismo para as massas", sendo que, na modernidade, a "morte de Deus" é o evento capaz não só de libertar o pensamento do jugo da moral, como também de dissolver a moral como instância de avaliação do tempo da vida (Aión). Como nos indica a narrativa dramática de "Assim falava Zaratustra", a "morte de

7 “Outras línguas, incluindo o grego, reúnem, num mesmo termo, o que dividimos em brincar e jogar. Constrangido a escolher, traduzimos paizo por jogar. Mais acertado estaríamos se disséssemos jogar-brincar" (SCHÜLER, 2007, p. 68).

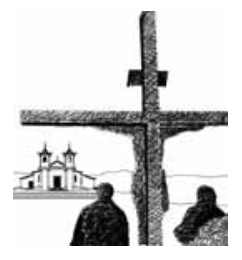


Deus" requer do homem a geração de uma nova experiência do tempo. Segundo Nietzsche, essa nova experiência será produzida na medida em que se afirme o "pensamento do eterno retorno". Em "Assim falava Zaratustra", Nietzsche mostra o dramático processo de incorporação desse pensamento, recuperando a figura da criança de Heráclito na produção dessa nova experiência humana do tempo.

O pensamento nietzscheano do eterno retorno aparece pela primeira vez no aforismo 341 de "Gaia ciência", intitulado "O maior dos pesos". Nesse aforismo, o eterno retorno é formulado como uma hipótese apresentada por um demônio:

O maior dos pesos. - E se um dia, ou uma noite, um demônio lhe aparecesse furtivamente em sua mais desolada solidão e dissesse: "Esta vida, como você a está vivendo ejá viveu, você terá de viver mais uma vez e por incontáveis vezes; e nada haverá de novo nela, mas cada dor e cada prazer e cada suspiro e pensamento, etudo o queé inefavelmente grande e pequeno em sua vida, terão de lhe suceder novamente, tudo na mesma seqüência e ordem - e assim também essa aranha e esse luar entre as árvores, e também este instante e eu mesmo. A perene ampulheta do existir será sempre virada novamente - e você com ela, partícula de poeira!" - Você não se prostraria e rangeria os dentes e amaldiçoaria o demônio que assim falou? Ou você já experimentou um instante imenso, no qual lhe responderia: "Você é um deus e jamais ouvi coisa tão divina!" Se esse pensamento tomasse conta de você, tal como vocêé, ele o transformaria e o esmagaria talvez; a questão em tudo e em cada coisa, "Você quer isso mais uma vez e por incontáveis vezes?", pesaria sobre os seus atos como o maior dos pesos! Ou o quanto você estaria de estar bem consigo mesmo e com a vida, para não desejar nada além dessa última, eterna confirmação e chancela? (NIETZSCHE, 2001, p. 230).

O filósofo apresenta dois estados despertados pela hipótese 80 lançada pelo demônio, dois estados distintos que apontam para 
duas atitudes distintas. Nietzsche impõe uma pergunta que indica o primeiro estado: "Você não se prostraria e rangeria os dentes e amaldiçoaria o demônio que assim falou?". Outro estado, também despertado pela hipótese demoníaca, revela uma atitude oposta, uma atitude afirmativa: “Ou você já experimentou um instante imenso, no qual lhe responderia: 'Você é um deus e jamais ouvi coisa tão divina!'”. Nietzsche apresenta que, na vigência de um certo instante extraordinário, a hipótese demoníaca seria afirmada. Através da caracterização nietzscheana da experiência humana do tempo, podemos vislumbrar o conteúdo dramático desse pensamento e a dificuldade que envolve a sua afirmação

Logo nos primeiros movimentos do parágrafo I da "II Extemporânea", intitulada "Da utilidade e desvantagem da história para a vida", Nietzsche caracteriza a singularidade da experiência humana do tempo:

Considera o rebanho que passa ao teu lado pastando: ele não sabe o que é ontem e o que é hoje; ele saltita de lá para cá, come, descansa, digere, saltita de novo; e assim de manhã até a noite, dia após dia; ligado de maneira fugaz com seu prazer e desprazer à própria estaca do instante, e, por isto, nem melancólico nem enfadado. Ver isto desgosta duramente o homem porque ele se vangloria de sua humanidade frente ao animal, embora olhe invejoso para a sua felicidade - pois o homem quer apenas isso, viver como o animal, sem melancolia, sem dor; e o quer entretanto em vão, porque não quer como o animal. $\mathrm{O}$ homem pergunta mesmo um dia ao animal: por que não me falas sobre tua felicidade $e$ apenas me observas? $\mathrm{O}$ animal quer também responder e falar, isso se deve ao fato de que sempre esquece o que queria dizer, mas também já esqueceu esta resposta e silencia: de tal modo que o homem se admira disso (NIETZSCHE, 2003, p. 7).

Os animais não sabem o que é o ontem e o hoje, ou seja, não constroem demarcações entre o presente e o passado que

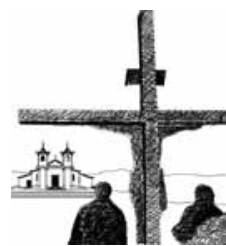

81 
possibilitem diferenciá-los. Os animais estão ligados "de maneira fugaz com seu prazer e desprazer à própria estaca do instante". Os animais estão presos a estaca do instante, porque as sensações de prazer e desprazer se encontram fechadas em si mesmas e, ao contrário do que acontece com o homem falante, não dão ensejo a nenhum processo contíguo, não são transpostas a outras articulações com a realidade.

Dessa forma, podemos construir a rede de articulações que media a relação dos homens com o devir, articulações que se originam da transposição das sensações de prazer e desprazer em "imagens perceptivas" e dessas aos próprios conceitos que demarcam profundamente a forma pela qual a experiência temporal dos homens se distingue da experiência dos animais. Ou seja, é a linguagem, à medida que torna possível o prolongamento das sensações de prazer e desprazer em sensações de imagem e a incorporação dessas num conceito, que é a verdadeira responsável pela singularidade da experiência humana do tempo frente aos outros animais. Por não assistirem a esse prolongamento, os animais nunca se apartam do instante em que as sensações têm lugar, devido a isso não podem experimentar um determinado instante em sua "diferencialidade" própria, portanto não sabem distinguir o ontem e o hoje.

Assim, os animais não estão submetidos a dois sentimentos tipicamente humanos: a melancolia e o enfado. O enfado surge do próprio peso que a experiência do passado descarrega sob o presente, que faz com que o próprio homem sinta inveja do animal e lembre com melancolia dos tempos de infância, em que ainda não sentia sobre si o peso do passado. Diz Nietzsche:

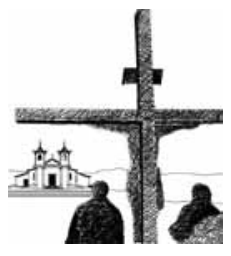

82

Assim, o animal vive a-historicamente: ele passa pelo presente como um número, sem que reste uma estranha quebra [...]. O homem, ao contrário, contrapõe-se ao grande e cada vez maior peso do que passou: este peso o oprime ou o inclina para o seu lado, incomodando os seus passos como um fardo invisível e obscuro que ele pode por vezes aparentemente negar e que, no convívio

Ano 13 - n. 15 - julho 2010 - p. 61-92 
com seus iguais, nega com prazer: para lhes despertar inveja. Por isso aflige, como se pensasse em um paraíso perdido, ver o gado pastando, ou, em uma proximidade mais familiar, a criança que ainda não tem nada a negar do passado e brinca entre os gradis do passado e do futuro em uma bem-aventurada cegueira. E, no entanto, é preciso que sua brincadeira seja perturbada: cedo demais a criança é arrancada ao esquecimento. Então ela aprende a entender a expressão "foi", a senha através da qual a luta, o sofrimento e o enfado se aproximam do homem para lembrá-lo o que é no fundo a sua existência um imperfectum que nunca pode ser acabado (NIETZSCHE, 2003, p. 8).

O progressivo peso do passado reveste a experiência humana do tempo com um conteúdo dramático. Na tentativa de livrar-se desse peso, o homem produziu valores que, segundo Nietzsche, revelam a vingança da vontade humana contra o tempo, o que marca profundamente a cultura ocidental e que tem no evento da "morte de Deus" um momento decisivo para ser dissolvida. Como diz Nietzsche, o homem inveja a criança, assim como o animal, por experimentar o instante que se encontra vedado ao adulto. Essa inveja faz com que o adulto arranque muito cedo a criança do esquecimento, obrigando-a a entrar na dramática experiência humana do tempo, afastando progressivamente a criança da experiência do instante, submetendo-a às suas configurações do passado ou às suas projeções do futuro.

$\mathrm{O}$ animal vive preso a estaca do instante, porque esquece. Esquece porque as sensações de prazer e desprazer não se prolongam para além do instante no qual têm lugar, esquecem porque essas sensações não geram sensações de imagens, reminiscências que retornam como fantasmas, perturbando a emergência de um instante posterior. Por outro lado, por vê-lo extinguir-se para sempre a cada vez, os animais não experimentam o instante em sua "diferencialidade" própria, o que segundo

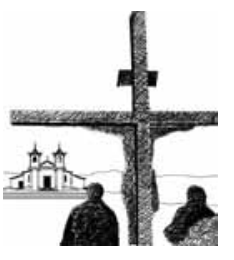


Schopenhauer permite afirmar que vivem num presente eterno.

De acordo com a "II Extemporânea", a dramática relação que o homem ostenta com a temporalidade encontra seu foco na não dissolução das configurações do passado que se mantêm presentes na memória, gerando o prolongamento de certo instante em que determinadas sensações de prazer e desprazer foram produzidas, e que o faz refém daquilo que passou. Na medida em que vislumbramos a maneira pela qual Nietzsche caracteriza a experiência humana do tempo, compreendemos o conteúdo dramático que envolve a hipótese demoníaca do eterno retorno e o sentido da postulação de que somente na vigência de um instante extraordinário esse pensamento seria afirmado.

Em "Assim falava Zaratustra", Nietzsche apresenta os desdobramentos dramáticos envolvidos na enunciação do eterno retorno. Nesse contexto, recuperando a figura da criança de Heráclito, nos convida a pensar na emergência de uma experiência temporal capaz de produzir a "transvaloração de todos os valores". Apesar de aparecer de maneira explicita somente na terceira parte da obra, nas seções "Da visão e do enigma" e "O convalescente", o cenário dramático no qual o pensamento do eterno retorno emerge é preparado desde os primeiros movimentos da obra. Para o propósito de pensar na ligação entre a figura da criança e o sentido da experiência do eterno retorno no interior do drama da Zaratustra, é fundamental analisar o discurso do personagem ainda na primeira parte da obra, intitulada "Das três metamorfoses do espírito". Nesse trecho, o filósofo nos convida mais uma vez a pensar a criança como portadora de outra experiência temporal.

Nessa seção, Zaratustra fala acerca de três transmutações do espírito. O espírito que realiza a primeira metamorfose transmuta-se em camelo, configura-se como espírito da suportação, suporta todo o peso das coisas já criadas, o peso do passado. Esse espírito pode conduzir aos "últimos homens", homens cansados que, esmagados pelo peso do passado histórico, já perderam toda a capacidade de criar.

O espírito como camelo "marcha carregado pelo deserto" 84 
(NIETZSCHE, 2003, p. 52), ambiente onde se dá a segunda transmutação: de camelo em leão. O espírito que se transmuta em leão luta contra a imposição gerada por aquilo que já foi criado, representada pela figura do dragão "tu deves". Dois aspectos são fundamentais nessa luta: a necessidade de se romper com o passado e, nesse movimento, "criar para si a liberdade para novas criações" (NIETZSCHE, 2003, p. 52). Zaratustra, acerca da segunda transmutação do espírito, lança uma questão: “Meus irmãos, para que é preciso o leão no espírito? Do que já não dá conta suficiente o animal de carga, suportador e respeitador?" (NIETZSCHE, 2003, p. 52). O personagem responde dizendo que aquilo que o espírito de suportação não dá conta é da criação de valores. Mas os novos valores criados podem submeter novamente o homem. Para que isso não ocorra, é necessário que o espírito se transmute em criança. Um novo começo, a possibilidade sempre renovada de um novo ordenamento do mundo é fundamental para que o passado não volte a submeter o homem aos valores já criados. Diz Zaratustra: “Inocência é a criança, e esquecimento; um novo começo, um jogo, uma roda que gira sobre si mesma, um movimento inicial, um sagrado dizer 'sim'” (NIETZSCHE, 2003, p. 53).

A terceira transmutação simboliza a passagem de um mundo regido pela legislação moral para um mundo regido pela legislação do jogo e a possibilidade de geração de uma disposição afirmativa diante do eterno retorno capaz de reverter o peso envolvido na hipótese demoníaca da eterna repetição de tudo na mesma sequência e ordem. É nesse sentido que, no interior da experiência nietzscheana do eterno retorno, podemos ver configurada uma imagem da criança capaz de modificar não só a crença num desenvolvimento linear e contínuo do homem, mas a própria experiência temporal humana e, dessa forma, reinventar o sentido da infância.

Para finalizarmos, apontaremos alguns elementos que sinalizam para a viabilidade dessa leitura, analisando, no interior do texto nietzscheano, a associação entre a figura da criança e o eterno retorno a partir da caracterização da experiência humana

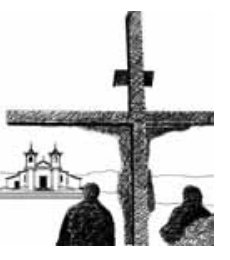


do instante apresentada na "II Extemporânea" e retomada na narrativa dramática de "Assim falava Zaratustra".

\section{Considerações finais}

O "eterno retorno" aparece pela primeira vez de maneira explicita em "Assim falava Zaratustra", na seção intitulada "Da visão e do enigma". O personagem aparece falando aos marinheiros sobre o espírito de gravidade, seu "demônio e mortal inimigo", personificado na figura de um Anão, que pula nas costas do personagem quando escalava sua mais alta montanha. Zaratustra adota um estilo argumentativo em seu diálogo com o Anão que só pode ser entendido na medida em que se compreende o sentido e os desdobramentos das imagens e metáforas construídas. O diálogo se passa em frente a um portal onde Zaratustra e Anão encontramse parados, no qual se assiste à junção entre dois caminhos, o que leva para trás e o que leva para frente, caminhos que duram uma eternidade. Esse portal representa o instante. $\mathrm{O}$ instante-portal divide o tempo infinito em duas metades, o passado e o futuro, metades que também duram uma eternidade.

Tendo em vista que o passado e o futuro, se encontram no instante, Zaratustra pergunta ao Anão se ao regressarmos ao passado ou nos projetarmos ao futuro, essas dimensões do tempo iriam contradizer-se eternamente. $\mathrm{O}$ questionamento conduz o Anão à conclusão de que o tempo é circular, conclusão que Zaratustra rejeita, qualificando-a como apressada e superficial. Na continuidade do diálogo, Zaratustra argumenta que diante da eternidade do passado, podemos afirmar que tudo que ocorre num determinado instante já deve ter acontecido pelo menos uma vez, inclusive o instante no qual ele e o Anão se encontram dialogando. O personagem diz ainda que, ao regressar ao passado, se contempla a infinitude da rua que leva para trás e se prolonga até o instante, salientando que ninguém a percorreu até o final. Mas então como vislumbrar que um dado instante repete um evento já transcorrido? 
É fundamental observar que os argumentos de Zaratustra não são conclusivos e que a conclusão é formulada pelo Anão, seu mortal inimigo. Os argumentos de Zaratustra são interrompidos pela enigmática visão de um pastor sendo devorado por uma serpente, a qual é melhor compreendida na seção "O convalescente", quando o personagem revela: "O grande fastio que sinto do homem - isto penetrava em minha goela e me sufocava; e aquilo que proclamava o advinho: 'Tudo é igual, nada vale a pena, o saber nos sufoca'” (NIETZSCHE, 2003, p. 261).

O pastor é o próprio Zaratustra e a serpente, o fastio que sente com relação aos homens diante da evidência de que não há progresso e aperfeiçoamento da humanidade, somente eterna repetição. $\mathrm{O}$ drama de Zaratustra se intensifica e a doutrina do Adivinho reaparece como um fantasma, conduzindo o personagem à convalescência. Essa doutrina, apresentada por Nietzsche ainda na segunda parte da obra, representa o desdobramento niilista da experiência do eterno retorno, que conduz ao esgotamento de todas as capacidades criativas do homem, que conduz aos últimos homens, ao homem cansado que perdeu toda capacidade de criar.

Para Paolo D’Iorio, esse desdobramento dramático está ligado à dificuldade de aceitar o eterno retorno sem se afetar pelos efeitos paralisantes e niilistas envolvidos numa concepção circular do tempo que aponta para o não-histórico, para a dissolução da experiência temporal humana, e afirmá-lo no mais alto grau de sentido histórico. Isso mostra que o eterno retorno nietzscheano não pode ser identificado com a concepção circular do tempo dos antigos, pois, como aponta a narrativa de "Assim falava Zaratustra", deve ser visto no interior de um projeto de redenção "no" tempo e não de um projeto de redenção "do" tempo, um projeto que incorpora o sentido histórico e não o dissolve. Por isso que a experiência do instante, crucial nesse embate de Zaratustra contra os desdobramentos niilistas do eterno retorno, é metaforizada na figura de um portal a partir do qual regressamos ao passado ou nos projetamos ao futuro.

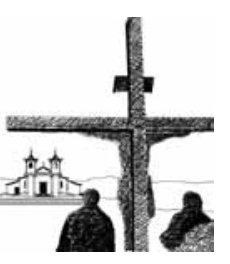


Nessa caracterização, podemos observar o esforço de Nietzsche em afirmar o pensamento do eterno retorno sem romper com as categorias de passado e de futuro, recompondo essas dimensões do tempo a partir da experiência do instante. Sendo assim, o rompimento com a concepção linear do tempo realizada pela experiência do eterno retorno nietzscheano não se estabelece a partir da retomada da circularidade estática dos antigos, mas através da repetição do instante. Essa formulação coloca novamente em questão o problema da experiência humana do instante em sua diferencialidade própria.

Apesar de assistirmos grandes mudanças no pensamento do filósofo da "II Extemporânea" para "Assim falava Zaratustra", principalmente no que se refere à posição assumida diante do sentido histórico, essa obra do período de juventude é crucial para a construção dos elementos que envolvem a formulação do eterno retorno à medida que coloca em questão o problema da vivência do instante em sua "diferencialidade" própria como o que distingue a experiência temporal humana. Podemos dizer que nessa formulação, a figura da criança emerge do interior da filosofia nietzscheana como elemento potencializador dessa experiência, que encontra na articulação entre memória e esquecimento, sua marca distintiva. No contexto da experiência do eterno retorno, a figura da criança se constitui como um elemento capaz de romper a vingança da vontade contra o tempo que, segundo Nietzsche, está na base de geração de todos os valores niilistas que negam a vida.

A dramática progressão retórica de enunciação do eterno retorno em "Assim falava Zaratustra" nos revela que tanto a concepção circular dos antigos como a concepção teleológica do tempo são marcadas por essa vingança. Nem o passado oracular, nem o futuro idealizado, o eterno retorno nietzscheano potencializa a experiência do instante para romper a vingança da vontade contra o tempo. Nesse registro, a figura da criança aparece dotada de um significado totalmente diferente daquele construído pela tradição. Pensando com Nietzsche, mas extrapolando o 
próprio texto nietzscheano, podemos nos questionar se não seria a identidade construída entre criança e infância um sintoma dessa vingança contra o tempo que se expressa através da relação que o homem estabelece com o fenômeno da natalidade.

Heráclito e Nietzsche são filósofos que nos convidam a observar como as imagens da criança estão vinculadas diretamente com a compreensão humana da temporalidade. Nesse sentido, nos fazem pensar que uma mudança radical nas caracterizações da figura da criança, como podemos encontrar no interior do pensamento desses filósofos, só é possível na medida em que uma nova experiência do tempo seja vislumbrada, o que atinge diretamente os processos educacionais. Como vimos, segundo Arendt, a crise na educação está diretamente ligada ao enfraquecimento da autoridade da tradição a que nos conduziu o pathos do novo que caracteriza a modernidade, ou seja, a crise está diretamente ligada a uma mudança nas relações do homem com o tempo.

Mas, por outro lado, a crise revela que a essência da educação se encontra no fenômeno da natalidade, no fato de seres novos nascerem num mundo velho. A crise nos colocou diante de uma discussão acerca da relação entre natalidade e experiência humana do tempo, denunciando no centro dessa reflexão o potencial que os processos educacionais possuem de roubar a novidade dos verdadeiramente novos, as crianças.

Nesse percurso, a leitura de Heráclito e Nietzsche pode nos colocar diante da emergência de um pensamento capaz de desconstruir a identidade, construída historicamente a partir das imagens do vir-a-ser adulto e da crença no devir progressivo do homem, entre criança e infância, e nos possibilitar pensar essa relação em outros termos, em que a criança, não mais caracterizada por um conjunto de ausências e marcada pelo "signo da falta", pode reinventar o sentido da infância. Dessa forma, transformar radicalmente o que chamamos de educação infantil, impossibilitando que esse seja o âmbito em que, em termos arendtianos, a novidade da criança é roubada.

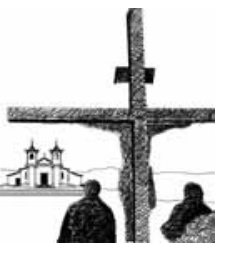




\section{Referências}

ARENDT, H. Entre o passado e o futuro. São Paulo: Perspectiva, 1997.

. A crise na educação. In: . Entre o passado e o futuro. Tradução de Celso Lafer. São Paulo: Perspectiva, 1997.

CASANOVA, M. A. O instante extra-ordinário: vida, história e valor na obra de Friedrich Nietzsche. Rio de Janeiro: Forense Universitária, 2003.

DELEUZE, G. Nietzsche e a filosofia. Rio de Janeiro: Ed. Rio, 1976

D'IORIO, P. Cosmologia e filosofia do eterno retorno. In: MARTON, S. (Org.). Nietzsche pensador mediterrâneo: a recepção italiana. São Paulo: GEN/Discurso Editorial/Editora Unijuí, 2007. (Coleção Sendas \& Veredas)

. La linea e il circolo. Cosmologia e filosofia dell'eterno ritorno in Nietzsche. Gênova: Pantograf, CNR, 1995.

ELIADE, M. O mito do eterno retorno. Lisboa: Edições 70, 1985.

FERNANDES, F. A investigação etnológica no Brasil e outros ensaios. Petrópolis: Vozes, 1975.

FOUCAULT, M. Vigiar e punir. São Paulo: Vozes, 1995

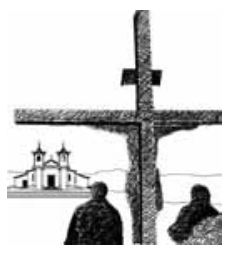
. Microfísica do poder. Rio de Janeiro: Graal, 1979.

FOUCAULT, G. (1972) Deleuze. Os intelectuais e o poder. In: . Microfísica do poder, 1999.

90 
Os anormais. Curso no Collège de France (1974-1975).

Tradução de Eduardo Brandão. São Paulo: Martins Fontes, 2001.

KLOSSOWSKI, P. Nietzsche et le cercle viciex. Rio de Janeiro:

Pazulin, 2000.

KOSSOVICH, L. Signos e poderes em Nietzsche. São Paulo: Ática, 1979.

KOHAN, W. O. Infância. Entre educação e filosofia. Belo Horizonte: Autêntica, 2003.

NIETZSCHE, F. W. O nascimento da tragédia ou helenismo e pessimismo. São Paulo: Companhia das Letras, 1993.

. Assim falava Zaratustra. Rio de Janeiro: Civilização Brasileira, 2003.

. Ecce homo. São Paulo: Companhia das Letras, 1995.

. Crepúsculos dos ídolos. Lisboa: Guimarães Editores, 1985.

. Obras incompletas. São Paulo: Nova Cultural, 1987.

. Gaia ciência. São Paulo: Companhia das Letras, 2001

. Segunda consideração intempestiva: da utilidade e desvantagem da história para a vida. Rio de Janeiro: RelumeDumará 2003.

A filosofia na idade trágica dos gregos. Rio de Janeiro: Elfos Ed.; Lisboa: Edições 70, 1995.

SCHÜLER, D. Heráclito e seu discurso. Porto Alegre: L\&PM, 2007.

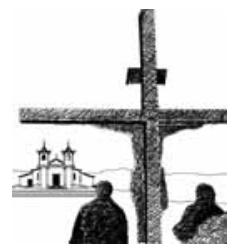

91 


\title{
Childhood, child and human experience of time
}

\begin{abstract}
:
The present work has as focus the problem of the identity between child and childhood, leaving of the characterization of important historical and philosophical elements involved in the construction of that identity, going by Heráclito, Plato, Nietzsche, Foucault and Hannah Arendt. To leave of that course it seeks to generate a reflection on the bases in which this identity is built, leaving of aspects that involve the characterization of the human experience of the time.
\end{abstract}

Keywords: Childhood; child; time; education; birth rate.

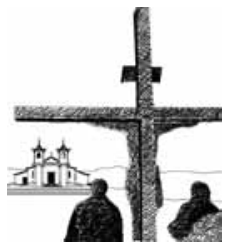

92

Ano 13 - n. 15 - julho 2010 - p. 61-92 